\title{
Optimization of Nutrients in Fermentative Lactic Acid Production Using Oil Palm Trunk Juice as Substrate
}

\author{
Nisa Saelee ${ }^{1,2}$, Klanarong Sriroth ${ }^{1}$ \\ ${ }^{1}$ Department of Biotechnology, Faculty of Agro-Industry, Kasetsart University, Bangkok, Thailand \\ ${ }^{2}$ Department of Biotechnology, Institute of Agricultural Technology, Walailak University, Nakhon Si Thammarat, \\ Thailand \\ Email: snisa@wu.ac.th
}

Received 14 August 2014; revised 18 September 2014; accepted 7 October 2014

Copyright (C) 2014 by authors and Scientific Research Publishing Inc.

This work is licensed under the Creative Commons Attribution International License (CC BY). http://creativecommons.org/licenses/by/4.0/

c) (i) Open Access

\begin{abstract}
Complex nutrients e.g. carbon, nitrogen, peptides, vitamin and salts significantly play important roles in lactic acid production efficiency depending on types of microorganism and sources of raw material. In this study oil palm trunk juice and Lactobacillus rhamnosus TISTR 108 (ATTC 10863) were utilized for lactic acid production. Additional nutrients including peptone, yeast extract and mixed salts were tested. Response surface methodology involving Box Behkhen Design (BBD) was applied to examine the optimal condition. Prediction of optimization was performed using full quadratic regression equation. The predicted maximum lactic acid concentration was obtained at $64.05 \mathrm{~g} \cdot \mathrm{l}^{-1}$ within a period of $48 \mathrm{~h}$ under an optimal condition of $10 \mathrm{~g} \cdot \mathrm{l}^{-1}$ peptone with mixed salts containing $0.4 \mathrm{~g} \cdot \mathrm{l}^{-1} \mathrm{MgSO}_{4} \cdot 7 \mathrm{H}_{2} \mathrm{O}, 0.1 \mathrm{~g} \cdot \mathrm{l}^{-1} \mathrm{MnSO}_{4} \cdot 4 \mathrm{H}_{2} \mathrm{O}, 3 \mathrm{~g} \cdot \mathrm{l}^{-1} \mathrm{~K}_{2} \mathrm{HPO}_{4}, 3 \mathrm{~g} \cdot \mathrm{l}^{-1} \mathrm{KH}_{2} \mathrm{PO}_{4}$ and $3 \mathrm{~g} \cdot \mathrm{l}^{-1}$ $\mathrm{CH}_{3} \mathrm{COONa} \cdot 3 \mathrm{H}_{2} \mathrm{O}$ in $250 \mathrm{ml}$ shake flask using $\mathrm{CaCO}_{3}$ as a titrant. Verification of optimization condition was performed in $2 \mathrm{l}$ fermenter using $\mathrm{Ca}(\mathrm{OH})_{2}$ as neutralizing agent. Increase in lactic acid fermentation was achieved at $92.81 \mathrm{~g} \cdot \mathrm{l}^{-1}$ at $48 \mathrm{~h}$ cultivation. The lactic acid yield and volumetric productivity were $0.94 \mathrm{~g}^{-\mathrm{g}^{-1}}$ and $1.91 \mathrm{~g} \mathrm{l}^{-1} \cdot \mathrm{h}^{-1}$, respectively. This suggests that OPT juice is potentially used as carbon and nutrient sources for lactic acid production.
\end{abstract}

\section{Keywords}

Lactic Acid, Oil Palm, Oil Palm Trunk Juice, OPT, Lactobacillus rhamnosus, Box Behkhen Design, BBD

\section{Introduction}

Oil palm, Elaesis guineensis is an important crop in Southeast Asia accounting for a total plantation area of

How to cite this paper: Saelee, N. and Sriroth, K. (2014) Optimization of Nutrients in Fermentative Lactic Acid Production Using Oil Palm Trunk Juice as Substrate. Advances in Bioscience and Biotechnology, 5, 957-965.

http://dx.doi.org/10.4236/abb.2014.512109 
proximately 9,746,666 - 14,620,000 hectares in 2013/2014. Nevertheless, an enormous number of old oil palm trees (20 - 25 years) were cut down for replanting due to their low productivity [1] [2]. Considering a significant number of abandoned oil palm trunks (OPTs) are discarded daily or every year. Many researchers have attempted to utilize OPT waste as a raw material to produce value-added products. In general, OPTs are industrially used to produce plywood [3] in which a large amount of juice squeezed from the OPT is the by-product. The squeezed juice containing high sugar contents has been used as a substrate for ethanol and lactic acid fermentation [4] [5].

Lactic acid and its derivatives have been widely used in industrial applications [6] [7]. In 2017, the annual worldwide lactic acid production is expected to reach 367,000 tons and the demand for lactic acid has been estimated to grow 5\% - 8\% yearly [8]. Manufacturing of lactic acid can be done using various methods; fermentation technique has been paid more attention according to the advantages in terms of stereo isomer selection, low substrate costs, mild conditions, low energy consumption and environmental friendliness [9]-[11]. However, efficient lactic acid fermentation by lactic acid bacteria requires complex nutrients depending on microorganism capabilities and growing environments such as temperature, $\mathrm{pH}$, oxygen, substrate and ongoing product concentration. Accordingly, the cost of raw materials is one of the limiting factors of the feasible economic production of lactic acid. Practically manufacturing sugars are utilized as carbon sources which are not cost-benefit for producing a cheap product of lactic acid. Using pure sugars for lactic acid production in industrial scale also requires supplementation including nitrogen sources, vitamins, minerals and growth factors.

Among various nitrogen sources, yeast extract leads to the highest lactic acid concentrations in a variety of nitrogen sources due to a wide range of growth factors including amino acids, vitamins, specific minerals, fatty acids, purines, and pyrimidines [12]. Cost of yeast extract is accounting for proximately $38 \%$ of the total production cost which is relatively high for economic benefit in industrial scale processes [13]. The alternative, cheaper nitrogen sources from organic nitrogen sources and agricultural by-products have been used as partial or total replacement of yeast extract, including peptone, soybean hydrolysate and soytone [14], corn steep liquor (CSL) [12], rice bran [15] [16], and wheat bran [17].

Considerably, addition of vitamins and mineral salts is required to enhance the lactic acid production [13]. Mineral salts such as phosphorous, magnesium, manganese, zinc, and iron are provided in the form of salts in a wide range of concentrations in the medium. In general, concentrations of $0.03-2.5 \mathrm{~g} \cdot \mathrm{l}^{-1} \mathrm{KH}_{2} \mathrm{PO}_{4}, 0.1-5 \mathrm{~g} \cdot \mathrm{l}^{-1}$ $\mathrm{MgSO}_{4}, 0.03-0.2 \mathrm{~g} \cdot \mathrm{l}^{-1} \mathrm{MnSO}_{4}, 0.02-0.03 \mathrm{~g} \cdot \mathrm{l}^{-1} \mathrm{FeSO}_{4}$ and $0.01-5 \mathrm{~g} \cdot \mathrm{l}^{-1} \mathrm{NaCl}$ have been used for lactic acid fermentation [13]-[16] [18]-[22].

According to our preliminary studies, OPT juice is considered suitable to be employed as high carbon and nutrient sources. However, nitrogen and salts content are considering insufficient in OPT juice in providing growth and lactic acid production by Lactobacillus rhamnosus TISTR 108 (ATTC 10863). This study investigated lactic acid production processes using OPT juice as a base medium. Response surface methodology (RSM) involving Box Behkhen design (BBD) and analysis of variance (ANOVA) were applied to find the appropriate components of yeast extract, peptone and salts solution in order to achieve maximum lactic acid production.

\section{Materials and Methods}

\subsection{Oil Palm Trunk Juice Preparation}

OPTs were obtained from local area in Nakhonsithammarat province, Thailand. OPTs were cut into small pieces and immediately squeezed using sugarcane press to collect OPT juice. The juice was centrifuged at $4000 \mathrm{rpm}$ for $40 \mathrm{~min}$ to remove the cellulosic debris. The clear supernatant of undiluted OPT juice was stored at $-18^{\circ} \mathrm{C}$ and further used as a fermentation base medium for lactic acid production.

\subsection{Microorganism and Culture Conditions}

The lactic acid bacteria used in this study was Lactobacillus casei subsp. rhamnosus TISTR 108 (ATTC 10863), purchased from Thailand Institute of Scientific and Technological Research (TISTR). The culture was grown and maintained on MRS broth (de Man Rogosa and Sharpe, Difco, USA) with 30\% glycerol. The strain was activated at $40^{\circ} \mathrm{C}$ for $48 \mathrm{~h}$ in MRS broth. The fermentation inoculum was prepared in a medium that contained, per liter of distilled water, $20 \mathrm{~g}$ glucose, $10 \mathrm{~g}$ bactotryptone, $10 \mathrm{~g}$ yeast extract, $2 \mathrm{~g} \mathrm{~K} \mathrm{HPO}_{4}, 5 \mathrm{~g} \mathrm{CH} \mathrm{COONa} \cdot 3 \mathrm{H}_{2} \mathrm{O}$, $0.2 \mathrm{~g} \mathrm{MgSO}_{4} \cdot 7 \mathrm{H}_{2} \mathrm{O}$ and $5 \mathrm{mg} \mathrm{MnSO}_{4} \cdot 4 \mathrm{H}_{2} \mathrm{O}$ [4]. The initial $\mathrm{pH}$ of the medium was adjusted to 7.0 with $6 \mathrm{~N}$ $\mathrm{NaOH}$ and conc. $\mathrm{HCl}$. After sterilization, the flask was inoculated and incubated at $40^{\circ} \mathrm{C}$ for $18 \mathrm{~h}$ with shaking 
speed of $150 \mathrm{rpm}$. The absorbance at $620 \mathrm{~nm}$ was adjusted to 4.0 as constant value before used as fermentation inoculum.

\subsection{Optimization Condition Using the Box Behkhen Design}

The fermentation conditions were optimized by response surface methodology (RSM) through the Box Behnken design (BBD) to fine the appropriate yeast extract (Difco, USA), peptone (Bacto Peptone, Difco, USA) and salts solution (all salts; $\mathrm{MgSO}_{4} \cdot 7 \mathrm{H}_{2} \mathrm{O}, \mathrm{MnSO}_{4} \cdot 4 \mathrm{H}_{2} \mathrm{O}, \mathrm{K}_{2} \mathrm{HPO}_{4}, \mathrm{KH}_{2} \mathrm{PO}_{4}, \mathrm{CH}_{3} \mathrm{COONa} \cdot 3 \mathrm{H}_{2} \mathrm{O}$ were analytical grade) concentrations to improve the efficiency of lactic acid fermentation on undiluted OPT juice by L. rhamnosus TISTR 108 (ATTC 10863). Three factors, namely peptone $(A)$, yeast extract $(B)$, and salts $(C)$ in three coded levels $(-1,0,+1)$ were evaluated. The factors $A, B$ and $C$ represent the independent variables. The lactic acid $(Y)$ is the response. Summary of variables, coded and uncoded values were shown in Table 1.

According to the design, 15 experiments were conducted in duplicates. The experiments were performed in $250 \mathrm{ml}$ Erlenmeyer flasks containing $100 \mathrm{ml}$ fermentation media with the addition of nutrients depending on the experiment design. One gram of $\mathrm{CaCO}_{3}$ was added to maintain $\mathrm{pH}$ 6.5. The fermentation experiments were conducted in $250 \mathrm{ml}$ Erlenmeyer flasks on the rotary shaker at $150 \mathrm{rpm}$ for $48 \mathrm{~h}$. The fermentation broth was heat at $70^{\circ} \mathrm{C}$ for $30 \mathrm{~min}$ and centrifuged at $1000 \mathrm{rpm}$ for $3 \mathrm{~min}$ to remove the $\mathrm{CaCO}_{3}$ pellet. Ten $\mathrm{ml}$ of the clear supernatant was measured and $16 \mathrm{ml}$ of $2 \mathrm{M} \mathrm{H}_{2} \mathrm{SO}_{4}$ was added to neutralize. The reaction tubes were left for complete precipitation and centrifuged at 10,000 rpm for $5 \mathrm{~min}$. The clear supernatant was diluted and filtered through $0.45 \mu \mathrm{m}$ (Millipore) before determination of sugars and lactic acid by HPLC.

Statistical analysis of the data was analyzed using the MINITAB statistical package. A full quadratic model was used to predict the optimal point, as the following equation:

$$
Y=b_{0}+b_{1} A+b_{2} B+b_{3} C+b_{12} A B+b_{13} A C+b_{23} B C+b_{11} A^{2}+b_{22} B^{2}+b_{33} C^{2}
$$

where $Y$ is predicted response (lactic acid concentration (g. $\left.l^{-1}\right)$ ), $b_{0}$ is intercept; $b_{1}, b_{2}$ and $b_{3}$ are linear coefficients, $b_{12}, b_{13}$ and $b_{23}$ are interaction coefficients, $b_{11}, b_{22}$ and $b_{33}$ are squared coefficients, $A, B$ and $C$ are the coded levels of the independent variables.

\subsection{Batch Fermentation Using Optimized Conditions}

The lactic acid fermentation under the optimization conditions of media obtained by response optimization was conducted in $2 \mathrm{l}$ fermenter containing $1.2 \mathrm{l}$ OPT juice based medium. The medium was autoclaved at $110^{\circ} \mathrm{C}$ for $10 \mathrm{~min}$ and $10 \%$ of L. rhamnosus TISTR 108 (ATTC 10863) was inoculated. The temperature and agitation speed were controlled at $40^{\circ} \mathrm{C}, 200 \mathrm{rpm}$, respectively. The $\mathrm{pH}$ was controlled by the automatic addition of $6 \mathrm{~N}$ $\mathrm{Ca}(\mathrm{OH})_{2}$ at $\mathrm{pH}$ 6.5. Samples were taken every $6 \mathrm{~h}$ intervals for $48 \mathrm{~h}$ to determine viable cells, lactic acid and sugar concentration.

\subsection{Analytical Methods}

Lactic acid and sugars contents in fermentation broth were analyzed by high pressure liquid chromatography (HPLC) system with Animex HPX 87H column, $300 \times 7.8 \mathrm{~mm}$ (BioRad, USA) with a refractive index detector (Waters, USA). The analytical condition was $5 \mathrm{mM} \mathrm{H}_{2} \mathrm{SO}_{4}$ mobile phase with a flow rate of $0.6 \mathrm{ml} \cdot \mathrm{min}^{-1}$ and column temperature of $50^{\circ} \mathrm{C}$. Bacterial growth in term of the number of viable cells was estimated using spreading plate technique on MRS agar. The incubation was performed in an anaerobic condition at $40^{\circ} \mathrm{C}$ in an anaerobic jar.

Table 1. Experimental design variables used in the Box Behkhen design.

\begin{tabular}{cccc}
\hline \multirow{2}{*}{ Factors } & \multicolumn{3}{c}{ Coded Units } \\
\cline { 2 - 4 } & -1 & 0 & 1 \\
\hline Peptone $\left(\mathrm{g} \cdot \mathrm{l}^{-1}\right)$ & 0 & 5 & 10 \\
Yeast extract $\left(\mathrm{g} \cdot \mathrm{l}^{-1}\right)$ & 0 & 10 & 20 \\
Salts concentrations & (a) & (b) & (c) \\
\hline
\end{tabular}

${ }^{\mathrm{a}} \mathrm{Salts}$ concentration (per liter). (a) Without salt addition; (b) $0.2 \mathrm{~g} \mathrm{MgSO}_{4} \cdot 7 \mathrm{H}_{2} \mathrm{O}, 0.05 \mathrm{~g} \mathrm{MnSO}_{4} \cdot 4 \mathrm{H}_{2} \mathrm{O}, 1.5 \mathrm{~g}$ $\mathrm{K}_{2} \mathrm{HPO}_{4}, 1.5 \mathrm{~g} \mathrm{KH}_{2} \mathrm{PO}_{4}$ and $1.5 \mathrm{~g} \mathrm{CH}_{3} \mathrm{COONa} \cdot 3 \mathrm{H}_{2} \mathrm{O}$ [23] and with (c) $=2 \times(\mathrm{b})$. 
Lactic acid yield $\left(\mathrm{Y}_{\mathrm{P} / \mathrm{S}}\right)$ and lactic acid productivity $\left(\mathrm{Q}_{\mathrm{P}}\right)$ were calculated as follow:

$$
\begin{gathered}
\mathrm{Y}_{\mathrm{P} / \mathrm{S}}=\frac{\Delta \mathrm{P}_{\mathrm{la}}}{\Delta \mathrm{S}_{\text {total }}}=\frac{\mathrm{P}_{\mathrm{la}}^{\mathrm{f}}-\mathrm{P}_{\mathrm{la}}^{\mathrm{i}}}{\mathrm{S}_{\text {total }}^{\mathrm{i}}-\mathrm{S}_{\text {total }}^{\mathrm{f}}} \\
\mathrm{Q}_{\mathrm{P}}=\frac{\Delta \mathrm{P}_{\mathrm{la}}}{\mathrm{t}}=\frac{\mathrm{P}_{\mathrm{la}}^{\mathrm{f}}-\mathrm{P}_{\mathrm{la}}^{\mathrm{i}}}{\mathrm{t}}
\end{gathered}
$$

where, $\mathrm{P}_{\mathrm{la}}^{\mathrm{f}}$ is the lactic concentration at the end of fermentation $\left(\mathrm{g} \cdot \mathrm{l}^{-1}\right)$. $\mathrm{P}_{\mathrm{la}}^{\mathrm{i}}$ is the lactic concentration at the beginning of fermentation $\left(\mathrm{g} \cdot \mathrm{l}^{-1}\right)$. $\mathrm{S}_{\text {total }}^{\mathrm{i}}$ is total sugars concentration at the beginning fermentation $\left(\mathrm{g} \cdot \mathrm{l}^{-1}\right) . \mathrm{S}_{\text {total }}^{\mathrm{f}}$ is total sugars concentration at the end of fermentation $\left(\mathrm{g} \cdot \mathrm{l}^{-1}\right)$. $\mathrm{t}$ is the fermentation time $(\mathrm{h})$.

\section{Results and Discussions}

\subsection{Media Optimization of Lactic Acid Production by Box Behkhen Design}

Box Behkhen design (BBD) showed to effectively describe the fermentation optimal conditions of $L$. rhamnosus TISTR 108 (ATTC 10863) using OPT juice as a base medium. The design matrix of the variables in coded units and responses of lactic acid concentration are shown in Table 2. The analysis of variance (ANOVA) for the quadratic model of lactic acid production is shown in Table 3 and the multiple regression analysis for lactic acid concentration is exhibited by the following equation.

Table 2. Observed and predicted lactic acid concentrations obtained from undiluted oil palm trunk juice fermentation with

\begin{tabular}{|c|c|c|c|c|c|}
\hline \multirow{2}{*}{ Run } & \multicolumn{3}{|c|}{ Coded Units } & \multicolumn{2}{|c|}{ Lactic Acid $\left(\mathrm{g} \cdot \mathrm{I}^{-1}\right)$} \\
\hline & A (Peptone, $\mathrm{g} \cdot \mathrm{l}^{-1}$ ) & $B$ (Yeast Extract, $\left.g \cdot \mathbf{l}^{-1}\right)$ & C (Mineral Salts) & Observed & Predicted \\
\hline 1 & -1 & 0 & 1 & 37.75 & 38.27 \\
\hline 2 & -1 & 0 & -1 & 37.23 & 34.16 \\
\hline 3 & 0 & -1 & -1 & 41.27 & 43.18 \\
\hline 4 & 1 & 0 & 1 & 53.52 & 56.50 \\
\hline 5 & -1 & -1 & 0 & 36.65 & 38.15 \\
\hline 6 & -1 & 1 & 0 & 38.63 & 41.03 \\
\hline 7 & 0 & 1 & -1 & 47.75 & 49.69 \\
\hline 8 & 0 & 0 & 0 & 43.72 & 42.14 \\
\hline 9 & 1 & -1 & 0 & 53.03 & 51.16 \\
\hline 10 & 0 & -1 & 1 & 58.47 & 57.29 \\
\hline 11 & 1 & 0 & -1 & 39.90 & 40.80 \\
\hline 12 & 0 & 0 & 0 & 42.04 & 42.14 \\
\hline 13 & 0 & 1 & 1 & 55.92 & 55.38 \\
\hline 14 & 1 & 1 & 0 & 54.18 & 52.89 \\
\hline 15 & 0 & 0 & 0 & 40.12 & 42.14 \\
\hline 16 & -1 & 0 & 1 & 38.94 & 38.27 \\
\hline 17 & -1 & 0 & -1 & 37.54 & 34.16 \\
\hline 18 & 0 & -1 & -1 & 42.15 & 43.18 \\
\hline 19 & 1 & 0 & 1 & 53.05 & 56.50 \\
\hline 20 & -1 & -1 & 0 & 36.14 & 38.15 \\
\hline 21 & -1 & 1 & 0 & 40.33 & 41.03 \\
\hline 22 & 0 & 1 & -1 & 48.29 & 49.69 \\
\hline 23 & 0 & 0 & 0 & 42.82 & 42.14 \\
\hline 24 & 1 & -1 & 0 & 52.39 & 51.16 \\
\hline 25 & 0 & -1 & 1 & 59.46 & 57.29 \\
\hline 26 & 1 & 0 & -1 & 41.55 & 40.80 \\
\hline 27 & 0 & 0 & 0 & 43.05 & 42.14 \\
\hline 28 & 0 & 1 & 1 & 57.79 & 55.38 \\
\hline 29 & 1 & 1 & 0 & 55.10 & 52.89 \\
\hline 30 & 0 & 0 & 0 & 41.07 & 42.14 \\
\hline
\end{tabular}
various nutrient supplementations by Box Behkhen design. 
Table 3. ANOVA results for nutrient optimization in lactic acid production from undiluted oil palm trunk juice by Box Behkhen design.

\begin{tabular}{ccccccc}
\hline Effect & DF & seq. SS & adj. SS & adj. MS & f Value & p Value \\
\hline Blocks & 1 & 3.01 & 3.01 & 3.010 & 0.59 & $0.451^{\mathrm{c}}$ \\
Regression & 9 & 1556.14 & 1556.14 & 172.904 & 34.06 & $0.000^{\mathrm{a}}$ \\
Linear & 3 & 1032.43 & 285.82 & 95.272 & 18.77 & $0.000^{\mathrm{a}}$ \\
$A$ & 1 & 619.04 & 7.60 & 7.602 & 1.50 & $0.236^{\mathrm{c}}$ \\
$B$ & 1 & 21.21 & 244.71 & 244.713 & 48.20 & $0.000^{\mathrm{a}}$ \\
$C$ & 1 & 392.18 & 12.45 & 12.481 & 2.16 & $0.133^{\mathrm{c}}$ \\
Square & 3 & 42.33 & 420.33 & 140.109 & 27.60 & $0.000^{\mathrm{a}}$ \\
$A^{*} A$ & 1 & 81.42 & 51.52 & 51.525 & 10.15 & $0.005^{\mathrm{a}}$ \\
$B^{*} B$ & 1 & 275.14 & 294.20 & 294.203 & 57.95 & $0.000^{\mathrm{a}}$ \\
$C^{*} C$ & 1 & 63.77 & 63.77 & 63.769 & 12.56 & $0.002^{\mathrm{a}}$ \\
Interaction & 3 & 103.38 & 103.38 & 34.459 & 6.79 & $0.003^{\mathrm{a}}$ \\
$A^{*} B$ & 1 & 0.67 & 0.67 & 0.668 & 0.13 & $0.721^{\mathrm{c}}$ \\
$A^{*} C$ & 1 & 67.24 & 67.24 & 67.238 & 13.24 & $0.002^{\mathrm{a}}$ \\
$B^{*} C$ & 1 & 35.47 & 35.47 & 35.472 & 6.99 & $0.016^{\mathrm{b}}$ \\
Residual Error & 19 & 96.46 & 96.46 & 5.077 & & 2.64 \\
Lack of Fit & 15 & 87.62 & 87.62 & 5.842 & & $0.179^{\mathrm{c}}$ \\
Pure Error & 4 & 8.83 & 8.83 & 2.209 & & \\
Total & 29 & 1655.61 & & & &
\end{tabular}

Note: the analysis was done using the coded units; ${ }^{\mathrm{a}}$ Significant at $\mathrm{p} \leq 0.01$; ${ }^{\mathrm{b}}$ Significant at $\mathrm{p} \leq 0.05$; ${ }^{\mathrm{c}}$ Non-significant; SS, sum of square; MS, mean square; DF, degree of freedom; $A, B$ and $C$ represent yeast extract, peptone and salt concentration, respectively.

$$
\begin{aligned}
Y= & 42.14+6.22 A+1.15 B+4.95 C-2.64 A^{2}+6.31 B^{2}+2.94 C^{2} \\
& -0.29 A B+2.90 A C-2.11 B C
\end{aligned}
$$

where $Y$ is the lactic acid production $\left(\mathrm{g} \cdot \mathrm{l}^{-1}\right), A, B$ and $\mathrm{C}$ is the coded levels for peptone, yeast extract and salts solutions $\left(\mathrm{g} \cdot \mathrm{l}^{-1}\right)$, respectively.

The full quadratic correlation for the estimated regression equation had $R^{2}$ of $94.17 \%$ and the predicted $R^{2}$ for lactic acid production was $84.06 \%$. The $\mathrm{R}^{2}$ value of $94.17 \%$ (close to $100 \%$ ) indicated that the variables including peptone, yeast extract and mineral salts contributed to a highly positive response and only about $5.83 \%$ cannot explained by this equation. The adjusted $\mathrm{R}^{2}$ of $91.11 \%$ indicated that the equation was highly accurate. The linear and quadratic effects of variables were significant at level of $p \leq 0.01$. The linear effect of yeast extract was significant at the level of $\mathrm{p} \leq 0.01$, whereas the linear effect of peptone and mineral salts was not significant. The square terms of peptone $\left(A^{2}\right)$, yeast extract $\left(B^{2}\right)$ and salts $\left(C^{2}\right)$ were highly significant $(\mathrm{p} \leq 0.01)$. The interaction terms $\left(A^{*} C, B^{*} C\right)$, were significant $(\mathrm{p} \leq 0.05)$ while the interaction terms between $A$ and $B$ was not significant. Lack of fit of this equation was not significant which indicated the good predictability of the equation. The significant linear and quadratic terms of parameters suggests that peptone, yeast extract and mineral salts can act as limiting nutrients for lactic acid production.

Response optimization condition of three coded variables using $1,-1,1$ for peptone, yeast extract and mineral salts was performed by the MINITAB program. The highest lactic acid concentration of $64.05 \mathrm{~g} \cdot \mathrm{l}^{-1} \mathrm{was} \mathrm{pre}-$ dicted at the optimum condition of peptone $10 \mathrm{~g} \cdot \mathrm{l}^{-1}$ and mineral salts containing $0.4 \mathrm{~g} \cdot \mathrm{l}^{-1} \mathrm{MgSO}_{4} \cdot 7 \mathrm{H}_{2} \mathrm{O}, 0.1$ $\mathrm{g} \cdot \mathrm{l}^{-1} \mathrm{MnSO}_{4} \cdot 4 \mathrm{H}_{2} \mathrm{O}, 3 \mathrm{~g} \cdot \mathrm{l}^{-1} \mathrm{~K}_{2} \mathrm{HPO}_{4}, 3 \mathrm{~g} \cdot \mathrm{l}^{-1} \mathrm{KH}_{2} \mathrm{PO}_{4}$ and $3 \mathrm{~g} \cdot \mathrm{l}^{-1} \mathrm{CH}_{3} \mathrm{COONa} \cdot 3 \mathrm{H}_{2} \mathrm{O}$. The 3D plots for the interactions between peptone $(A)$ and mineral salts $(C)$ of lactic acid fermentation are shown in Figure 1 . It can be noticed that by increasing the peptone and mineral salts, the lactic acid production from undiluted OPT juice was increased. Furthermore, the fermentation of undiluted OPT juice under the optimized condition of nutrient supplementation obtained by BBD were performed to validate the empirical equation. The maximum lactic acid concentration of $63.2 \pm 3.45 \mathrm{~g} \cdot \mathrm{l}^{-1}$ was obtained experimentally and this was close to the predicted valve of 64.05 $\mathrm{g} \cdot \mathrm{l}^{-1}$. However, it is important to note that this experiment was performed in $250 \mathrm{ml}$ Erlenmeyer flask which $\mathrm{CaCO}_{3}$ was used as a titrant. This optimized nutrient condition was then further evaluated in a $2 \mathrm{l}$ fermenter (with $1.2 \mathrm{l}$ working volume), using $\mathrm{Ca}(\mathrm{OH})_{2}$ as a neutralizing agent. 


\subsection{Batch Fermentation of Lactic Acid Production under Optimized Conditions}

The profiles of cell growth, sugar and lactic acid concentration during lactic acid production from undiluted OPT juice with optimized nutrient supplementation in a fermenter are presented in Figure 2 and some kinetic parameters are summarized in Table 4. The high lactic acid concentration of $92.81 \mathrm{~g} \cdot \mathrm{l}^{-1}$ was obtained with yield of $0.94 \mathrm{~g} \cdot \mathrm{g}^{-1}$ and productivity of $1.91 \mathrm{~g} \cdot \mathrm{l}^{-1} \cdot \mathrm{h}^{-1}$ at $48 \mathrm{~h}$ fermentation. The highest cells of L. rhamnosus TISTR 108 (ATTC 10863) of $1.35 \times 10^{11} \mathrm{cfu} \cdot \mathrm{ml}^{-1}$ was achieved at $30 \mathrm{~h}$ cultivation in the optimized medium compositions. However, some residual sugars were present at the end of fermentation time. The incomplete sugar consumption might be caused by some inhibitory effect as indicated by lower viable cells $\left(<10^{11} \mathrm{cfu} \cdot \mathrm{ml}^{-1}\right)$. In this study, the statistical approaches were successfully applied and overcame the limitation of empirical method. The use of peptone and salts could improve lactic acid production by L. rhamnosus TISTR 108 (ATTC 10863). Study of Abdul Karim, et al. [24] indicated that peptone provided the best lactic acid production by L. rhamnosus
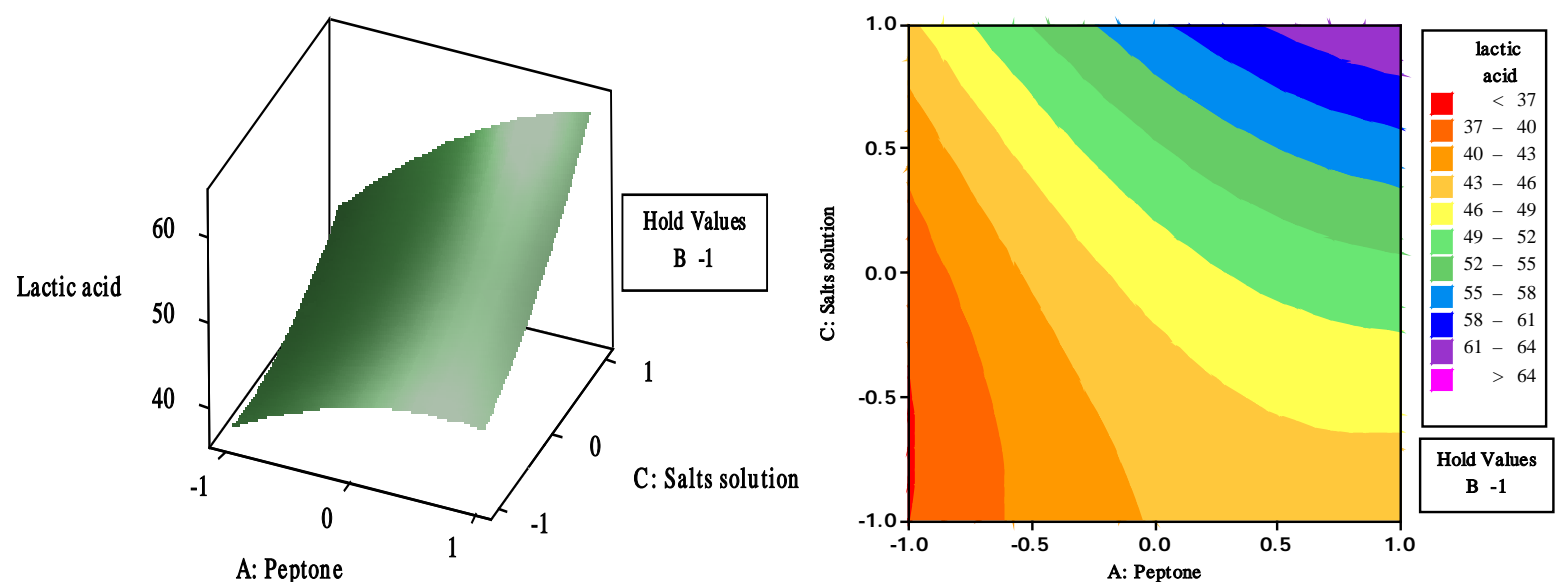

Figure 1. Response surface and contour plots of lactic acid concentration during fermentation of undiluted oil palm trunk juice by Lactobacillus rhamnosus TISTR 108 (ATTC 10863), showing the interaction between peptone (A) and mineral salts (C).

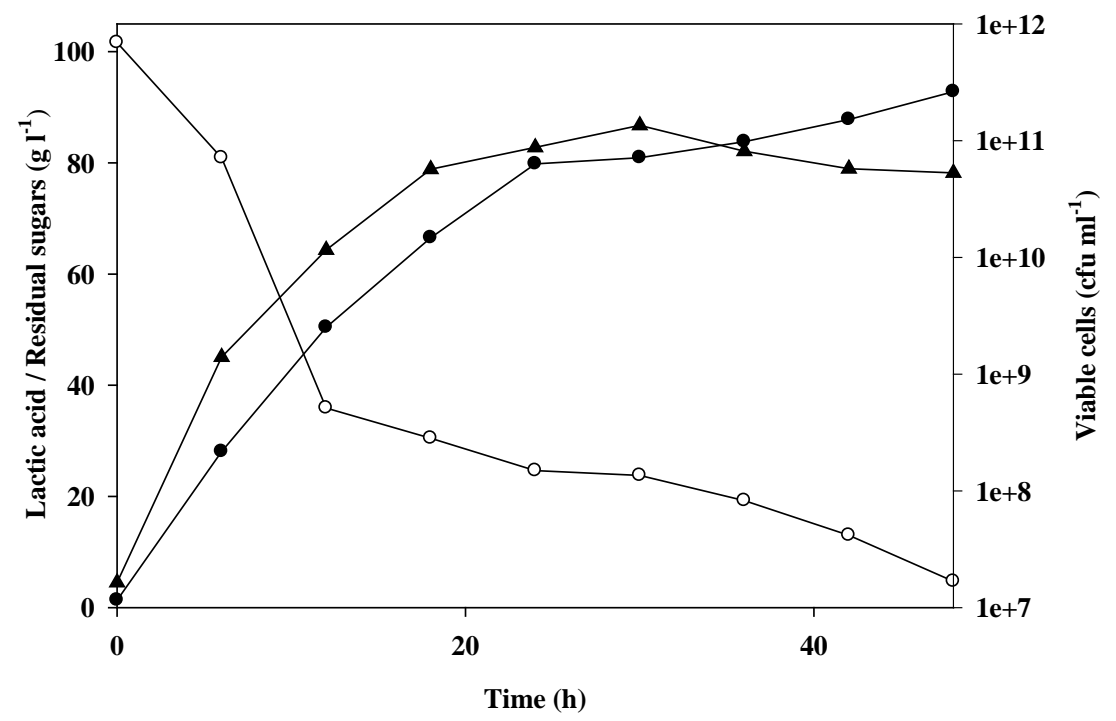

Figure 2. Profiles of cell growth, sugar and lactic acid concentrations during lactic acid fermentation of undiluted oil palm trunk juice with statistically optimized nutrient supplementation by Lactobacillus rhamnosus TISTR 108 (ATTC 10863). The batch fermentation was performed in $2 \mathrm{l}$ fermenter with $1.2 \mathrm{l}$ working volume at $40^{\circ} \mathrm{C}$, $\mathrm{pH} 6.5$ and the agitation speed of $200 \mathrm{rpm}$, using $10 \%$ inoculum; lactic acid $(\bullet)$, residual sugars (o) and viable cells $(\boldsymbol{\Delta})$. 
Table 4. Kinetic parameters of lactic acid fermentation on undiluted oil palm trunk juice by Lactobacillus rhamnosus TISTR 108 (ATTC 10863) with nutrient supplementation, optimized by Box Behkhen design.

\begin{tabular}{cc}
\hline Parameters & Values \\
\hline Fermentation time $(\mathrm{h})$ & 48 \\
Lactic acid $\left(\mathrm{g} \cdot \mathrm{l}^{-1}\right)$ & 92.81 \\
$\mathrm{Y}_{\mathrm{P} / \mathrm{S}}\left(\mathrm{g} \cdot \mathrm{g}^{-1}\right)$ & 0.94 \\
$\mathrm{Q}_{\mathrm{P}}\left(\mathrm{g} \cdot \mathrm{l}^{-1} \cdot \mathrm{h}^{-1}\right)$ & 1.91 \\
Residual sugars $\left(\mathrm{g} \cdot \mathrm{l}^{-1}\right)$ & 4.71 \\
\hline
\end{tabular}

Note: the fermentation was conducted in 21 fermenter using undiluted OPT juice, at $40^{\circ} \mathrm{C}, \mathrm{pH}$ 6.5 with $10 \%$ inoculums and agitation speed of $200 \mathrm{rpm}$.

comparing to yeast extract in MRS medium containing the same amount of glucose. Even though, OPT juice was rich in carbon source but the amount of nitrogen and salts were low and not enough for efficient lactic acid production. Many studies reported high lactic acid yields and productivities by statistical optimization [25] [26]-[30]. John et al. [31] used Box Behnken design to optimize the production of L(+)-lactic acid by Lactobacillus casei and Lactobacillus delbrueckii and lactic acid yield was obtained at $81 \mathrm{~g} \cdot \mathrm{l}^{-1}$.

\section{Conclusion}

The predicted equation has confirmed that the proper amount of peptone and salts supplementation was essential for lactic acid production by L. rhamnosus TISTR 108 (ATTC 10863) on OPT juice fermentation. The findings in this study demonstrate the potential use of undiluted OPT juice as a cheap carbon source for lactic acid production. In term of economic benefits, the fermentative lactic acid production cost varies depending on various factors and raw material cost is considerably high. The OPT is generally an agricultural waste, and OPT juice extract is an industrial by-product when fiber was separated for plywood processing. According to lab-scale process based on the juice production per one trunk, approximately $19.7-22.7$ tons of OPT juice could be obtained from a hectare of plantation area. Considering a vast area of oil palm plantation in Southeast Asian region, a large amount of OPT juice can inundate the industry demand for fermentative lactic acid production. However, fermentation process techniques in large scale have yet to be improved.

\section{Acknowledgements}

This work was supported by Kasetsart University and Walailak University, Thailand.

\section{References}

[1] The United States Department of Agriculture (2014) Palm Oil Production 2014/2015. http://www.worldpalmoilproduction.com/?gclid=COGHid6Hx78CFdMXjgodoSsAzw

[2] Department of Agriculture Extension (2014) Palm Replanting in 5 Provinces of Southern Thailand (in Thai). http://thainews.prd.go.th/centerweb/News/NewsDetail?NT01_NewsID=TNECO5706100010044sthash.Yja24vwV.dpuf

[3] Mokhtar, A., Hassan, K., Abdul Aziz, A. and Wahid, M.B. (2011) Plywood from Oil Palm Trunks. Journal of Oil Palm Research, 23, 1159-1165.

[4] Kosugi, A., Tanaka, R., Magara, K., Murata, Y., Arai, T., Sulaiman, O., Hashim, R., Abdul Hamid, Z.A., Yahya, M.K.A., Yosof, M.N.M., Ibrahim, W.A. and Mori, Y. (2010) Ethanol and Lactic Acid Production Using Sap Squeezed from Old Oil Palm Trunks Felled for Replanting. Journal of Bioscience and Bioenergy, 110, 322-325.

[5] Yamada, H., Tanaka, R., Sulaiman, O., Hashim, R., Hamid, Z.A.A., Yahya, M.K.A., Kosugi, A., Arai, T., Murata, Y., Nirasawa, S., Yamamoto, K., Ohara, S., Yusof, M.N.M., Ibrahim, W.A. and Mori, Y. (2010) Old Oil Palm Trunk: A Promising Source of Sugars for Bioethanol Production. Biomass and Bioenergy, 34, 1608-1613. http://dx.doi.org/10.1016/j.biombioe.2010.06.011

[6] Wee, Y.J., Kim, J.N. and Ryu, H.W. (2006) Biotechnological Production of Lactic Acid and Its Recent Applications. Food Technology and Biotechnology, 44, 163-173.

[7] Castillo Martinez, F.A., Balciunas, E.M., Salgado, J.M., Dominguex, J.M., Converti, G.A. and De S. Oliveira, R.P. 
(2013) Lactic Acid Properties, Application and Production: A Review. Trends in Food Science and Technology, 30, 70-83. http://dx.doi.org/10.1016/j.tifs.2012.11.007

[8] Abdel-Rahman, M.A., Tashiro, Y. and Sonomoto, K. (2013) Recent Advances in Lactic Acid Production by Microbial Fermentation Processes. Biotechnology Advances, 31, 877-902. http://dx.doi.org/10.1016/j.biotechadv.2013.04.002

[9] Narayanan, N., Roychoudhury, P.K. and Srivastava, A. (2004) L(+) Lactic Acid Fermentation and Its Product Polymerization. Electronic Journal of Biotechnology, 7, 167-179.

[10] Mussatto, S.I., Fernandes, M., Mancilha, I.M. and Roberto, I.C. (2008) Effects of Medium Supplementation and pH Control on Lactic Acid Production on Brewer's Spent Grain. Biochemical Engineering Journal, 40, 437-444. http://dx.doi.org/10.1016/j.bej.2008.01.013

[11] Gao, C., Ma, C. and Xu, P. (2011) Biotechnological Routes Based on Lactic Acid Production from Biomass. Biotechnology Advances, 29, 930-939. http://dx.doi.org/10.1016/j.biotechadv.2011.07.022

[12] Yu, L., Lei, T., Ren, X., Pei, X. and Feng, Y. (2008) Response Surface Optimization of L-(+)-Lactic Acid Production Using Corn Steep Liquor as an Alternative Nitrogen Source by Lactobacillus rhamnosus CGMCC 1466. Biochemical Engineering Journal, 39, 496-502. http://dx.doi.org/10.1016/j.bej.2007.11.008

[13] Nancib, A., Nancib, N., Meziane-Cherif, D., Boubendir, A., Fick, M. and Boudrant, J. (2005) Joint Effect of Nitrogen Sources and B Vitamin Supplementation of Date Juice on Lactic Acid Production by Lactobacillus casei subsp. rhamnosus. Bioresource Technology, 96, 63-67. http://dx.doi.org/10.1016/j.biortech.2003.09.018

[14] Kwon, S., Lee, P.C., Lee, E.G., Chang, Y.K. and Chang, N. (2000) Production of Lactic Acid by Lactobacillus rhamnosus with Vitamin-Supplemented Soybean Hydrolysate. Enzyme and Microbial Technology, 26, 209-215. http://dx.doi.org/10.1016/S0141-0229(99)00134-9

[15] Gao, M.T., Kaneko, M., Hirata, M., Toorisaka, E. and Hano, T. (2008) Utilization of Rice Bran as Nutrient Source for Fermentative Lactic Acid Production. Bioresource Technology, 99, 3659-3664. http://dx.doi.org/10.1016/j.biortech.2007.07.025

[16] Li, Z., Lu, J., Yang, Z., Han, L. and Tan, T. (2012) Utilization of White Rice Bran for Production of L-Lactic Acid. Biomass and Bioengy, 39, 53-58. http://dx.doi.org/10.1016/j.biombioe.2011.12.039

[17] Li, Z., Han, L., Ji, Y., Wang, X. and Tan, T. (2010) Fermentative Production of L-Lactic Acid from Hydrolysate of Wheat Bran by Lactobacillus rhamnosus. Biochemical Engineering Journal, 49, 138-142. http://dx.doi.org/10.1016/j.bej.2009.10.014

[18] Nancib, N., Nancib, A., Boudjelal, A., Benslimane, C., Blanchard, F. and Boudrant, J. (2001) The Effect of Supplementation by Different Nitrogen Sources on the Production of Lactic Acid from Date Juice by Lactobacillus casei subsp. rhamnosus. Bioresource Technology, 78, 149-153. http://dx.doi.org/10.1016/S0960-8524(01)00009-8

[19] Yuwono, S.D. and Kokugan, T. (2008) Study of the Effects of Temperature and pH on Lactic Acid Production from Fresh Cassava Roots in Tofu Liquid Waste by Streptococcus bovis. Biochemical Engineering Journal, 40, 175-183. http://dx.doi.org/10.1016/j.bej.2007.12.004

[20] Gao, M.T., Hirata, M., Toorisaka, E. and Hano, T. (2009) Development of a Fermentation Process for Production of Calcium-L-Lactate. Chemical Engineering Processing: Process Intensification, 48, 464-469. http://dx.doi.org/10.1016/j.cep.2008.06.002

[21] Ge, X.Y., Qjan, H. and Zhang, W.G. (2009) Improvement of L-Lactic Acid Production from Jerusalem Artichoke Tubers by Mixed Culture of Aspergillus niger and Lactobacillus sp. Bioresource Technology, 100, 1872-1874. http://dx.doi.org/10.1016/j.biortech.2008.09.049

[22] Liu, B., Yang, M., Qi, B., Chen, X., Su, Z. and Wan, Y. (2010) Optimizing L-(+)-Lactic Acid Production by Thermophile Lactobacillus plantarum As.1.3 Using Alternative Nitrogen Sources with Response Surface Method. Biochemical Engineering Journal, 52, 212-219. http://dx.doi.org/10.1016/j.bej.2010.08.013

[23] Timbuntam, W. (2008) Development of Technology for Lactic Acid Production from Cassava Starch. Ph.D. Thesis, Kasertsart University, Bangkok.

[24] Abdul Karim, M.I., Mel, M., Jamal, P., Mohamed Salleh, M.R. and Alanin, N. (2006) Media Screening of Lactic Acid Fermentation Using Lactobacillus rhamnosus. Journal of Agricultural Technology, 2, 203-210.

[25] Payot, T., Chemaly, Z. and Fick, M. (1999) Lactic Acid Production by Bacillus coagulans-Kinetic Studies and Optimization of Culture Medium for Batch and Continuous Fermentations. Enzyme and Microbial Technology, 24, 191-199. http://dx.doi.org/10.1016/S0141-0229(98)00098-2

[26] Bustos, G., Moldes, A.B., Alonso, J.L. and Vazquez, M. (2004) Optimization of D-Lactic Acid Production by Lactobacillus coryniformis Using Response Surface Methodology. Food Microbiology, 21, 143-148. http://dx.doi.org/10.1016/S0740-0020(03)00061-3

[27] Gullon, Z., Yanez, R., Alonso, J.L. and Parajo, J.C. (2008) L-Lactic Acid Production from Apple Pomace by Sequen- 
tial Hydrolysis and Fermentation. Bioresource Technology, 99, 308-319. http://dx.doi.org/10.1016/j.biortech.2006.12.018

[28] Lu, X., Lu, M., He, F. and Yu, L. (2009) An Economical Approach for D-Lactic Acid Production Utilizing Unpolished Rice from Aging Paddy as Major Nutrient Source. Bioresource Technology, 100, 2026-2031. http://dx.doi.org/10.1016/j.biortech.2008.10.015

[29] Lu, Z., He, F., Shi, Y., Lu, M. and Yu, L. (2010) Fermentative Production of L-(+)-Lactic Acid Using Hydrolyzed Acorn Starch, Persimmon Juice and Wheat Bran Hydrolysate as Nutrients. Bioresource Technology, 101, 3642-3648. http://dx.doi.org/10.1016/j.biortech.2009.12.119

[30] Sun, J., Zhu, J. and Li, W. (2012) L-(+) Lactic Acid Production by Rhizopus oryzae Using Pretreated Dairy Manure as Carbon and Nitrogen Source. Biomass and Bioenergy, 47, 442-450. http://dx.doi.org/10.1016/j.biombioe.2012.09.011

[31] John, R.P., Sukumaran, R.K., Nampoothiri, K.M. and Pandy, A. (2007) Statistical Optimization of Simultaneous Saccharification and L(+)-Lactic Acid Fermentation from Cassava Bagasse Using Mixed Culture of Lactobacilli by Response Surface Methodology. Biochemical Engineering Journal, 36, 262-267. http://dx.doi.org/10.1016/j.bej.2007.02.028 
Scientific Research Publishing (SCIRP) is one of the largest Open Access journal publishers. It is currently publishing more than 200 open access, online, peer-reviewed journals covering a wide range of academic disciplines. SCIRP serves the worldwide academic communities and contributes to the progress and application of science with its publication.

Other selected journals from SCIRP are listed as below. Submit your manuscript to us via either submit@scirp.org or Online Submission Portal.
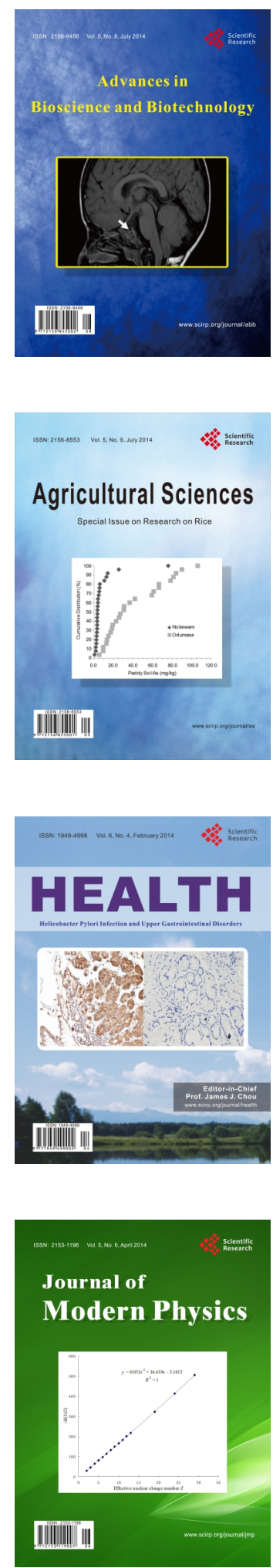
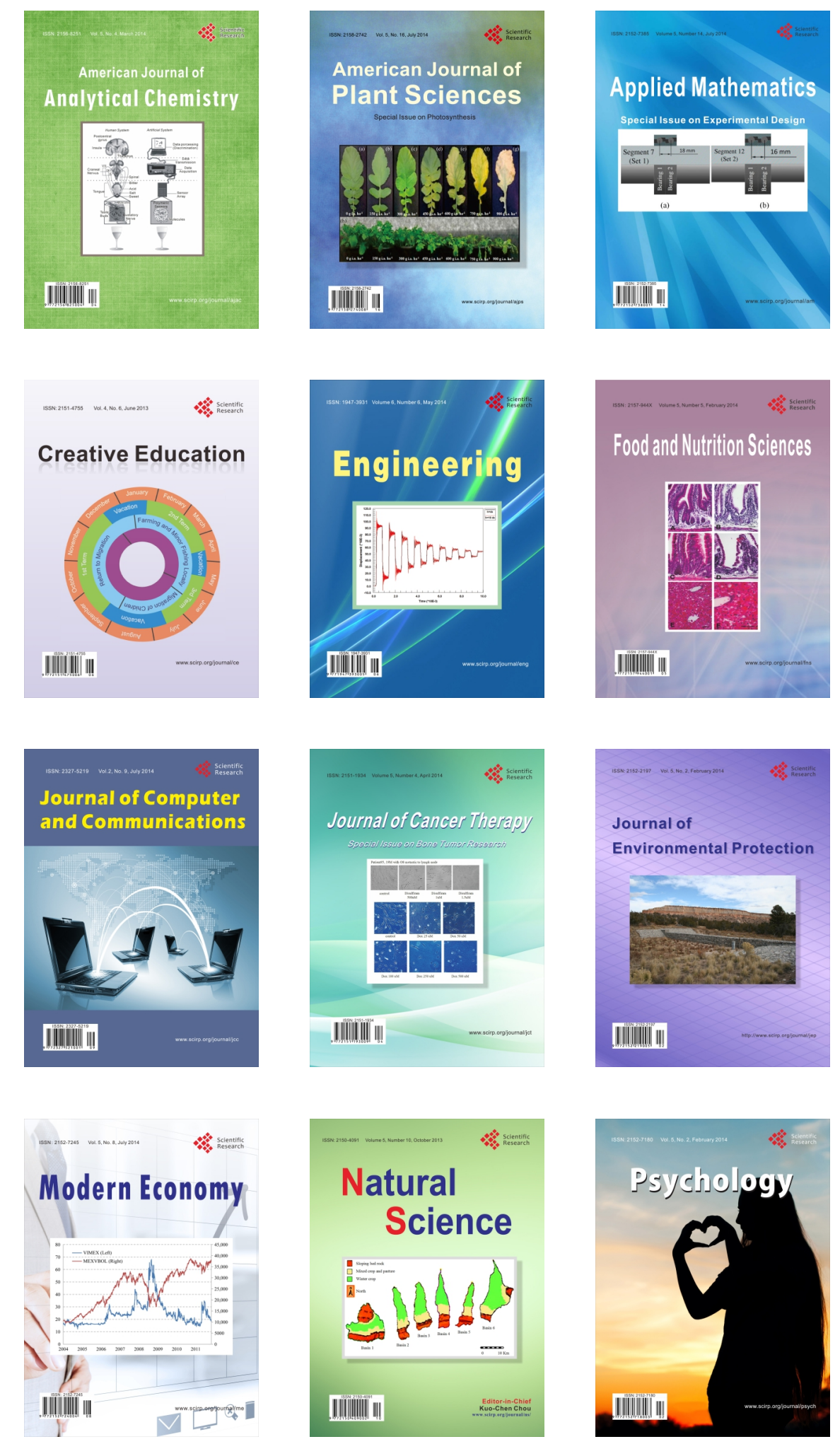